Brit. f. vener. Dis. (1969), 45, 33.

\title{
SERO-DIAGNOSIS OF GONORRHOEA WITH A MICROPRECIPITIN TEST USING A LIPOPOLYSACCHARIDE ANTIGEN FROM $N$. gonorrhoeae*
}

\author{
C. W. CHACKO $†$ AND G. M. NAIR
}

Central V.D. Reference Laboratory, Institute of Venereology, Madras Medical College, Madras 3, India

Serum tests for gonorrhoea, particularly the complement-fixation procedure using whole gonococcal cells as the antigen, have long been recognized to be of very limited value in diagnosis. For more efficient diagnosis and control of gonorrhoea there is clearly a need for a simple serological method which can be used as a screening test aimed particularly at the detection of the female carrier in circumstances in which discretion is required and in which routine genital examination is not practicable.

In this context a simple "microprecipitin ring test", using a specific lipopolysaccharide antigen of gonococcal origin, has been devised. Preliminary trials have shown its possible usefulness (Chacko and Nair 1966a). The present report gives the results of a more extensive evaluation. The kinetics of the precipitin ring test were described by Nair and Chacko (1966).

\footnotetext{
Material and Methods

Preparation of the Antigen The specific antigen was prepared as follows:

A 24-hour growth of a virulent strain of gonococcus (F62-type r, obtained through the courtesy of the VDRL, Atlanta, U.S.A.) grown in Chacko-Nair selective medium (1966b, r968) was emulsified in broth and $0.1 \mathrm{ml}$. aliquots were inoculated into the allantoic cavity of 8-day-old chick embryos through the air sac. Eggs were candled periodically and at the end of 48 hours' infection and growth of gonococci, they were kept in the refrigerator at $4^{\circ} \mathrm{C}$ for 2 to 4 hours. The allantoic fluid was then aspirated under sterile conditions using a ro-ml. syringe and an 18-gauge needle and the purity of the cultures was checked by Gram-staining and sub-culture.

Next, the allantoic fluid was centrifuged lightly to remove all the macroscopic and fat particles. It was then pipetted into large centrifuge bottles and six

$\star$ Received for publication September 12, 1967

tProfessor of Serology

$\neq$ Assistant Serologist
}

volumes of absolute alcohol were added; the mixture was shaken thoroughly and kept at 5 to $10^{\circ} \mathrm{c}$ for 24 to 48 hours. The contents were then centrifuged at 2,000 r.p.m. for one hour, the supernatant was discarded, and any excess alcohol burnt off. Half the original volume of double-distilled deionized water was added to the precipitate, which was then homogenized by using a $5-\mathrm{ml}$. pipette, was again centrifuged at 2,000 r.p.m. for one hour, and the supernatant watery extract pipetted out. An equal quantity of absolute alcohol was added and centrifuged at 2,000 r.p.m. for 30 minutes. To the supernatant, 6 volumes of absolute alcohol were again added, followed by a trace of sodium acetate and 4 to 8 $\mathrm{ml}$. glacial acetic acid, the whole was mixed well and kept in the cold for 2 hours. The contents were centrifuged at 2,000 r.p.m. for 45 minutes and the deposit was dissolved in a volume of water one-eighth of the original volume of culture fluid taken. After further centrifugation to remove all the insoluble particles, the slightly turbid supernatant so obtained was titrated to obtain the exact units of antigen necessary for the test, as follows:

Doubling dilutions of the original antigen preparation were made in double-distilled water. A known reactive gonococcal serum was taken in a series of capillary tubes (described below) and the undiluted antigen and its various dilutions were carefully overlaid, so as to form a clear junction of the two fluids. The tubes were incubated at $37^{\circ} \mathrm{C}$. for 30 minutes and the reciprocal of the highest dilution of the antigen which gave a $2+$ ring reaction was taken as the titre of the antigen. Sodium chloride was added in such a way that it contained a 0.125 Molar strength in 2 units per unit volume after the addition of other reagents. The antigen was then adjusted to $\mathrm{pH}$ 7, using B.D.H. wide-range indicator paper. A clear saturated aqueous solution of "Auromine O", which serves as indicator and sensitizer, was added drop by drop, to give it a sparkling greenishyellow colour. Normal $\mathrm{NaOH}$ was now added drop by drop, with constant agitation until the whole mixture turned milky-white, in order to complete the sensitization of the antigenic particles. Normal $\mathrm{HCl}$ was then added drop by drop with constant agitation, till the 
milky-white suspension turned into a clear, sparkling greenish-yellow solution. The $\mathrm{pH}$ was checked to be 6 to 7 and double-distilled water at $\mathrm{pH} 6$ to 7 was added to this sensitized antigen so that the final volume contained 2 units of antigen per unit volume. The prepared antigen was preserved in divided quantities at minus $20^{\circ} \mathrm{C}$, and brought back to room temperature when required for use.

Wooden racks of $20 \mathrm{~cm}$. long, I cm. wide, and $3 \mathrm{~cm}$. high (total height $4.5 \mathrm{~cm}$.), with thirteen holes $5 \mathrm{~mm}$. in diameter and $1 \cdot 5 \mathrm{~cm}$. apart were made locally for holding the test-tubes.

Capillary tubes of $2 \mathrm{~mm}$. internal and $4 \mathrm{~mm}$. external diameter and $40 \mathrm{~mm}$. long were made in the laboratory for use as special test-tubes. Pasteur pipettes with narrow capillary endings were used to transfer the reagents. Kahn tubes were used for dilution purposes.

The specimens of blood for this investigation (from known gonorrhoea, non-gonorrhoea, and other cases) were obtained from patients attending the Madras Institute of Venereology, and the Madras Institute of Obstetrics and Gynaecology, additional specimens came from the Government General Hospital Blood Bank. Sera were used as fresh as possible and without inactivation. Material for culture of the gonococcus was obtained from the genito-urinary passages wherever possible, and the bacterial diagnosis of gonorrhoea was based on the culture of uro-genital secretions on the egg-enriched Chacko-Nair medium.

Microprecipitin Test The sera from the blood samples were separated immediately after their receipt and were tested as follows:

Qualitative Test The serum was taken to a height of 15 to $18 \mathrm{~mm}$. in the capillary tube of $2 \mathrm{~mm}$. internal diameter and an equal amount of the antigen was overlaid using the Pasteur pipette so as to form a clear junction of the two liquid reagents. Known positive sera of various strengths and known negative sera were included as "controls". The tubes were incubated at $37^{\circ} \mathrm{C}$. for I hour and the readings were made semiquantitatively as, $\pm 1+, 2+, 3+$, and $4+$, depending upon the density and width of the "precipitin-rings" formed. A $2+$ reaction was taken as the minimum reading for a "positive reaction" qualitatively.
Quantitative Test. Doubling dilutions of the positive serum were made in 0.85 per cent. $\mathrm{NaCl}$ and each dilution was tested as an individual serum. The reciprocal of the last dilution of the serum which showed $2+$ reaction was taken as the end-point of the precipitin reaction and was expressed as "titre of the reaction in dilutions".

\section{Results}

The results are presented in Tables $I$ to $V$.

\section{Discussion}

Reising and Kellogg (1965) described a "microprecipitin test" using a phenol extract of cultured $N$. gonorrhoeae, but its overall sensitivity of 62 per cent. positive results in 186 cases of proven cases of gonorrhoea suggests that it was inadequate as a screening test.

In this study, another "microprecipitin test" has been devised, employing an antigen that is claimed to be lipopolysaccharide in nature and precipated with alcohol from the allantoic fluid of embryonated chick eggs in which $N$. gonorrhoeae had been grown to maintain virulence. Table I shows that this test was reactive in 60 per cent. of 28 cases of gonorrhoea of 1 to 3 days' duration, in 95 per cent. of 38 cases of 4 to 6 days' duration and in 100 per cent. of 60 cases of 7 days' duration and over, giving an overall sensitivity of 88 per cent. of 126 cases of acute untreated gonorrhoea in males. These results suggest a much greater sensitivity in comparison with the microprecipitin test using phenol extract antigen.

It is possible that, even in the early stage of gonorrhoea when the infection is restricted to the urethra, specific humoral antibody against the gonococcus is produced and continues to increase in quantity as the infection persists. The antibody may be detected as early as the third day of the infection if a sufficiently sensitive serological technique is available, as in this study.

TABLE I

SENSITIVITY OF THE MICROPRECIPITIN TEST ASSESSED AGAINST CASES OF GONORRHOEA FROM WHICH N. GONORRHOEAE HAVE BEEN ISOLATED IN CULTURE, IN THE CHACKO-NAIR EGG-ENRICHED SELECTIVE

\begin{tabular}{|c|c|c|c|c|c|c|c|c|c|c|c|c|c|c|}
\hline \multirow{3}{*}{$\begin{array}{c}\text { Duration } \\
\text { of Urethral } \\
\text { Discharge } \\
\text { (days) }\end{array}$} & \multirow{3}{*}{$\begin{array}{c}\text { No. } \\
\text { Tested }\end{array}$} & \multirow{3}{*}{$\begin{array}{c}\text { No. } \\
\text { Reactive }\end{array}$} & \multirow{3}{*}{$\begin{array}{l}\text { Percentage } \\
\text { Sensitivity }\end{array}$} & \multicolumn{6}{|c|}{ Qualitative Reading of Reactions } & \multicolumn{5}{|c|}{ Quantitative Reactions (dilutions) } \\
\hline & & & & \multicolumn{3}{|c|}{ Non-reactive } & \multicolumn{3}{|c|}{ Reactive } & & & & & \\
\hline & & & & - & \pm & + & ++ & +++ & $1+t+$ & (undiluted) & 2 & 4 & 8 & 16 \\
\hline \multirow{3}{*}{$\begin{array}{c}1 \text { to } 3 \\
4 \text { to } 6 \\
7 \text { to } 10 \\
10 \text { and } \\
\text { above }\end{array}$} & 28 & 16 & 60 & 2 & 5 & 5 & 16 & - & - & 15 & 1 & - & - & - \\
\hline & $\begin{array}{l}38 \\
33\end{array}$ & $\begin{array}{l}36 \\
33\end{array}$ & $\begin{array}{r}95 \\
100\end{array}$ & 二 & 1 & 1 & $\begin{array}{l}28 \\
15\end{array}$ & $\begin{array}{r}8 \\
15\end{array}$ & $\overline{3}$ & 29. & $\begin{array}{r}5 \\
25\end{array}$ & $\begin{array}{l}2 \\
4\end{array}$ & 二 & 二 \\
\hline & 27 & 27 & 100 & - & - & - & - & 7 & 20 & 一 & 7 & 11 & 8 & 1 \\
\hline Total & 126 & 112 & 88 & 2 & 6 & 6 & 59 & 30 & 23 & 48 & 38 & 17 & 8 & 1 \\
\hline
\end{tabular}

The tests performed qualitatively and quantitatively tend to show increase in titre with duration of infection. 
Acute gonococcal urethritis in the male is detected comparatively easily by standard methods of smear and/or culture, but in the female diagnosis by smear is not so reliable and cultural investigation is not always practicable as a routine. In some cases results of smears and cultures may reverse from positive to negative, or sporadic positive cultures may be obtained after a relatively long series of negative results. In these circumstances, a sensitive serum test for gonorrhoea would be most valuable in screening female patients who may be asymptomatic carriers. Table IIA shows that this test was reactive in 6 ( 4 per cent.) of 146 pregnant women who had no signs or symptoms of any venereal infection and were screened during ante-natal examinations. In later cultural investigation of these cases, gonococci were isolated from two women, one of whom was reactive and the other

TABLE IIA

RESULTS IN FEMALE CASES IN WHICH GONORRHOEA WAS EXCLUDED BY CULTURAL'EXAMINATION

\begin{tabular}{|c|c|c|c|c|c|c|c|c|c|c|c|c|}
\hline \multirow{3}{*}{$\begin{array}{l}\text { Source of } \\
\text { Specimens }\end{array}$} & \multirow{3}{*}{$\begin{array}{l}\text { No. } \\
\text { Tested }\end{array}$} & \multicolumn{3}{|c|}{ Culture } & \multirow{3}{*}{$\begin{array}{l}\text { Percentage } \\
\text { Specificity }\end{array}$} & \multicolumn{6}{|c|}{ Qualitative Reaction } & \multirow{3}{*}{$\begin{array}{c}\text { No. of Specimens } \\
\text { in which VDRL } \\
\text { Test for } \\
\text { Syphilis was } \\
\text { Reactive }\end{array}$} \\
\hline & & \multirow{2}{*}{ Positive } & \multirow{2}{*}{ Negative } & \multirow{2}{*}{$\begin{array}{c}\text { Non- } \\
\text { reactive }\end{array}$} & & \multicolumn{3}{|c|}{ Non-reactive } & \multicolumn{3}{|c|}{ Reactive } & \\
\hline & & & & & & - & \pm & + & ++ & $1+++1$ & $1+++$ & \\
\hline \multirow{2}{*}{$\begin{array}{l}\text { Pregnant } \\
\text { Females } \\
\text { Gynaecological } \\
\text { Patients }^{7}\end{array}$} & 146 & $2^{1}$ & 144 & 140 & 97 & 141 & - & - & $5^{2}$ & - & - & $4^{3}$ \\
\hline & $\begin{array}{l}140 \\
100\end{array}$ & $6^{4}$ & 94 & 85 & 90 & $\begin{array}{r}141 \\
85\end{array}$ & - & - & $14^{5}$ & 1 & - & $8^{6}$ \\
\hline
\end{tabular}

Notes 1. One of two culture-positive cases was reactive, and the other was non-reactive to the microprecipitin test.

2. VDRL test was non-reactive in these five cases.

3. Microprecipitin test was non-reactive in these four cases.

4. Five of six cases were reactive and one was non-reactive in the microprecipitin test.

5. VDRL test was reactive in four cases.

6. Microprecipitin test was reactive in four cases.

7. Four of these gynaecological patients were reactive to both VDRL tests for syphilis and the test for gonorrhoea.

$\star \quad$ Non-reactive cases $\times 100$

No. of cases culture-negative $=$ Specificity per cent.

TABLE IIB

RESULTS IN APPARENTLY NON-GONOCOCCAL NORMAL SUBJECTS IN WHOM CULTURE INVESTIGATION WAS NOT DONE

\begin{tabular}{|c|c|c|c|c|c|c|c|c|c|c|c|c|c|c|}
\hline \multirow{3}{*}{$\begin{array}{l}\text { Source of } \\
\text { Specimens }\end{array}$} & \multirow{3}{*}{$\begin{array}{l}\text { No. } \\
\text { Tested }\end{array}$} & \multirow{3}{*}{$\begin{array}{l}\text { No. } \\
\text { Non- } \\
\text { reactive }\end{array}$} & \multirow{3}{*}{$\begin{array}{l}\text { Percentage } \\
\text { Specificity }\end{array}$} & \multicolumn{6}{|c|}{ Qualitative Reaction } & \multicolumn{5}{|c|}{$\begin{array}{c}\text { Quantitative Titre } \\
\text { (dilutions) }\end{array}$} \\
\hline & & & & \multicolumn{3}{|c|}{ Non-reactive } & \multicolumn{3}{|c|}{ Reactive } & \multirow{2}{*}{$\begin{array}{c}\text { No. of } \\
\text { Specimens } \\
\text { Tested }\end{array}$} & \multirow{2}{*}{1} & \multirow{2}{*}{2} & \multirow{2}{*}{4} & \multirow{2}{*}{8} \\
\hline & & & & & \pm & + & +4 & $+1+4$ & $\mid+\overline{t+t}$ & & & & & \\
\hline $\begin{array}{l}\text { Normal Males (laboratory } \\
\text { staff) }\end{array}$ & 10 & 10 & 100 & - & - & - & - & - & - & - & - & - & - & - \\
\hline $\begin{array}{l}\text { Antenatal Cases at the } \\
\text { Women and Children's } \\
\text { Hospital, Madras }\end{array}$ & 232 & 212 & 91 & 200 & 10 & 2 & 17 & 3 & - & 20 & 8 & 6 & 6 & 6 \\
\hline $\begin{array}{l}\text { Blood-donors at the General } \\
\text { Hospital, Madras }\end{array}$ & 86 & 81 & 94 & 76 & 2 & 3 & 4 & 1 & - & 2 & 1 & 1 & - & - \\
\hline
\end{tabular}

TABLE IIC

MICROPRECIPITIN TEST ASSESSED AGAINST VENEREAL DISEASES OTHER THAN MANIFEST GONORRHOEA

\begin{tabular}{|c|c|c|c|c|c|c|c|c|c|c|c|c|c|c|}
\hline \multirow{3}{*}{ Clinical Category } & \multirow{3}{*}{$\begin{array}{l}\text { No. } \\
\text { Tested }\end{array}$} & \multirow{3}{*}{$\begin{array}{l}\text { No. } \\
\text { Non- } \\
\text { reactive }\end{array}$} & \multirow{3}{*}{$\begin{array}{l}\text { Percentage } \\
\text { Specificity }\end{array}$} & \multicolumn{6}{|c|}{ Qualitative Reaction } & \multicolumn{5}{|c|}{$\begin{array}{c}\text { Quantitative Titre } \\
\text { (dilutions) }\end{array}$} \\
\hline & & & & \multicolumn{3}{|c|}{ Non-reactive } & \multicolumn{3}{|c|}{ Reactive } & \multirow{2}{*}{$\begin{array}{c}\text { No. of } \\
\text { Specimens } \\
\text { Tested }\end{array}$} & \multirow{2}{*}{1} & \multirow{2}{*}{2} & \multirow{2}{*}{4} & \multirow{2}{*}{8} \\
\hline & & & & - & \pm & + & $+t$ & $++4+4$ & ++++ & & & & & \\
\hline $\begin{array}{l}\text { Known syphilis cases } \\
\text { reactive to VDRL test* } \\
\text { Urethritis cases in which } \\
\text { smear and culture were } \\
\text { negative for } N . \text { gonorrhoeae }\end{array}$ & $\begin{array}{r}148 \\
44\end{array}$ & $\begin{array}{r}117 \\
41\end{array}$ & $\begin{array}{l}80 \\
93\end{array}$ & $\begin{array}{l}99 \\
38\end{array}$ & $\begin{array}{l}8 \\
1\end{array}$ & 10 & $\begin{array}{l}19 \\
3\end{array}$ & - & - & - & 3 & - & 一 & - \\
\hline
\end{tabular}

$\star$ In two, gonococci were isolated in culture.

Specificity $=\frac{117 \times 100}{146}=80$ per cent. 
non-reactive to the microprecipitin test. In 100 female patients in a gynaecological clinic similarly investigated, six were culture-positive for the gonococcus, and fifteen (including five of the six) were reactive to the microprecipitin test.

In another group of 232 pregnant women who were investigated at random by testing their blood alone (Table IIB), this microprecipitin test was reactive in twenty ( 9 per cent.). In yet another group of 363 women, who had attended the Venereal Diseases clinic and were non-reactive to the VDRL test (Table III), the microprecipitin test for gonorrhoea was found to be reactive in 115 (32 per cent.).

Obviously, with the apparently high sensitivity observed in known cases of gonorrhoeae, this test has shown its value in discovering possible cases of gonococcal infection in the females studied, in that the percentage of positive results ranged from 4 to 32 in proportion to the patients' liability to exposure to venereal infection. It must be stressed, however, that a positive reaction indicates only an "immunologic status" and may relate to either past or present infection; clearly such sero-reactive cases also require further clinical, epidemiological, and laboratory investigations before a final diagnosis is made.

Table IV shows that further investigation of the 115 sero-reactions derived from the 363 females screened by this test revealed that 110 had "abnormal vaginal discharge". Eight patients including four with vaginal discharge had signs and symptoms of "arthritis" suggestive of gonococcal origin, 26 complained of dysuria in addition to vaginal discharge and five gave a history of previous acute urethritis and cervicitis regarded as gonococcal. Another 44 patients gave histories of a venereal disease and specific treatment thereof. Finally, from 23 (20 per cent.) of 115 sero-positive females gonococci were later isolated in culture confirming active infection. For the remaining 80 per cent. of the sero-positive cases, evidence supported by circumstantial clinical and historical findings did seem to suggest past or present infection with gonorrhoea which would not otherwise have been recognized.

In male cases similarly investigated in this study 5 of 86 blood-donors tested at random were found to be reactive (Table IIB). In a group of 148 cases with positive reactions to the VDRL test for

TABLE III

RESULTS OF MICROPRECIPITIN TEST IN PATIENTS ATTENDING THE MADRAS VD INSTITUTE IN WHOM THE VDRL TEST FOR SYPHILIS WAS NON-REACTIVE, BY SEX]

\begin{tabular}{|c|c|c|c|c|c|c|c|c|c|c|c|}
\hline \multirow{3}{*}{ Sex } & \multirow{3}{*}{$\begin{array}{l}\text { No. } \\
\text { Tested }\end{array}$} & \multirow{3}{*}{$\begin{array}{c}\text { No. } \\
\text { Reactive }\end{array}$} & \multirow{3}{*}{$\begin{array}{l}\text { Percentage } \\
\text { Reactivity }\end{array}$} & \multirow{2}{*}{\multicolumn{3}{|c|}{ Qualitative Reaction }} & \multicolumn{5}{|c|}{ Quantitative Test (dilutions) } \\
\hline & & & & & & & No. of & & & & \\
\hline & & & & ++ & +++ & $+t+$ & $\begin{array}{l}\text { Specimens } \\
\text { Tested }\end{array}$ & 1 & 2 & 4 & 8 \\
\hline $\begin{array}{l}\text { Male } \\
\text { Female }\end{array}$ & $\begin{array}{l}975 \\
363\end{array}$ & $\begin{array}{l}314 \\
115\end{array}$ & $\begin{array}{l}32 \\
32\end{array}$ & $\begin{array}{r}219 \\
83\end{array}$ & $\begin{array}{l}57 \\
20\end{array}$ & $\begin{array}{l}38 \\
12\end{array}$ & $\begin{array}{l}78 \\
12\end{array}$ & $\begin{array}{r}37 \\
7\end{array}$ & $\begin{array}{r}27 \\
3\end{array}$ & $\begin{array}{r}11 \\
1\end{array}$ & $\begin{array}{l}3 \\
1\end{array}$ \\
\hline Total & 1,338 & 429 & 32 & 302 & 77 & 50 & 90 & 44 & 30 & 12 & 4 \\
\hline
\end{tabular}

TABLE IV

CLINICAL CONDITION OF 115 SERO-REACTIVE FEMALES ATTENDING A VD CLINIC

\begin{tabular}{|c|c|c|c|c|c|c|}
\hline \multirow[b]{2}{*}{ Major Complaint } & \multirow[b]{2}{*}{ No. of Cases } & \multicolumn{2}{|c|}{ Definite History } & \multicolumn{2}{|c|}{$\begin{array}{l}\text { Gonorrhoea diagnosed by } \\
\text { Re-examination and Culture } \\
\text { of } N \text {. gonorrhoeae from } \\
\text { Vaginal Discharge }\end{array}$} & \multirow{2}{*}{$\begin{array}{c}\text { Not definitely } \\
\text { diagnosed for } \\
\text { want of } \\
\text { Laboratory } \\
\text { Evidence }\end{array}$} \\
\hline & & $\begin{array}{c}\text { Acute } \\
\text { Urethritis and } \\
\text { Cervicitis } \\
\text { (treated or } \\
\text { untreated) }\end{array}$ & $\begin{array}{l}\text { VD Other than } \\
\text { Recognized } \\
\text { Urethritis } \\
\text { (treated) }\end{array}$ & $\begin{array}{l}\text { Contact } \\
\text { Unknown }\end{array}$ & $\begin{array}{c}\text { Contact } \\
\text { treated for } \\
\text { Gonorrhoea } \\
\text { Simultaneously }\end{array}$ & \\
\hline $\begin{array}{l}\text { Abnormal vaginal discharge } \\
\text { Arthritis-like symptoms } \\
\text { Non-specific symptoms, burning } \\
\text { on micturition, genital pruritus }\end{array}$ & $\begin{array}{c}110^{\star} \\
8 \\
26\end{array}$ & $\begin{array}{c}5 \\
-\end{array}$ & $\begin{array}{r}28 \\
4 \\
12\end{array}$ & $\frac{10}{1}$ & $\frac{12}{-}$ & $\begin{array}{r}88 \\
8 \\
25\end{array}$ \\
\hline Total & 115 & $5\left(4^{\circ} \%\right)$ & $44(40 \%)$ & $\frac{11(10 \%)}{23}$ & $\frac{12(10 \%)}{0 \%)}$ & $\begin{array}{l}(121-29)= \\
92=80 \%\end{array}$ \\
\hline
\end{tabular}

*Two also had rectal discharge. 
syphilis, this test was reactive in 31 (20 per cent.). In another group of $\mathbf{4 4}$ male cases of urethritis in which active gonococcal infection was excluded by negative culture tests the microprecipitin test was reactive in 3 ( 7 per cent.) (Table IIC).

975 males who attended the VD Clinic and were non-reactive to the routine VDRL test for syphilis were screened again with this serological test for gonorrhoea; 314 (32 per cent.) were found to be reactive (Table III). On further investigation, 12 per cent. of these 314 sero-reactive patients gave a history suggestive of past gonococcal infection, treated or untreated; 21 per cent. had been treated for a venereal infection other than gonorrhoea. As regards risk of infection, 85 per cent. admitted extra-marital exposure, and 9 per cent. admitted leading a promiscuous sex life; only 6 per cent. denied extra-marital exposure. On clinical examination, although they presented various signs and symptoms suggestive of gonococcal infection (Table $\mathrm{V}$ ), the gonococcus was isolated in culture in only two of the 314 cases.

Thus, in this study, of 1,338 patients of both sexes who were "non-reactive" to the VDRL test for syphilis, 429 (32 per cent.) were "reactive" to the microprecipitin test for gonorrhoea (Table III). In contrast, of 148 in the same group, who were "reactive" to the VDRL test for syphilis, only 31 (21 per cent.) were reactive to the microprecipitin test for gonorrhoea (Table IIC). This gives an overall sero-reactivity to possible gonococcal infection of 31 per cent. of 1,486 persons liable to infection with venereal disease.

As far as the "specificity" of this microprecipitin test is concerned, the results of the study were as follows:
In all of ten apparently healthy members of the laboratory staff the test was non-reactive (Table IIB)

In 146 apparently normal pregnant women in whom gonococcal infection had been excluded by negative cultures, this test was non-reactive in 140, a specificity of 97 per cent. (Table IIA). The 3 per cent. of seroreactive cases may possibly have been due to past infection with the gonococcus.

In another group of 232 pregnant women in whom past or present infection with the gonococcus had not been established or excluded, the specificity of this test was 91 per cent.

In another group of 94 women with gynaecological disorders, in whom active infection with the gonococcus had been excluded by culture, the specificity was 90 per cent. (Table IIA). These were sexually active mature females from a socioeconomic class known to be exposed to risk of venereal diseases. The gonococcus had been isolated in culture from six of the original 100 cases in this group. It may be also noted that the VDRL test for syphilis was positive in eight cases, four of which were also reactive to the serological test for gonorrhoea.

In the 86 blood-donors, the 6 per cent. reactivity to the serological test for gonorrhoea must be viewed against the observation that 10 per cent. of 4,538 blood-donors from the same socio-economic class in Madras City were reactive to the VDRL test for syphilis during 1966.

In 44 cases of non-gonococcal urethritis the specificity of this serological test for gonorrhoea was 93 per cent. (Table IIA).

It has been interesting to compare our results with those of Reising and Kellogg (1965), who employed a phenol extract of $N$. gonorrhoeae in

TABLE V

CLINICAL CONDITION OF 314 MALES ATTENDING VD CLINIC WHO WERE REACTIVE TO THE MICROPRECIPITIN TEST

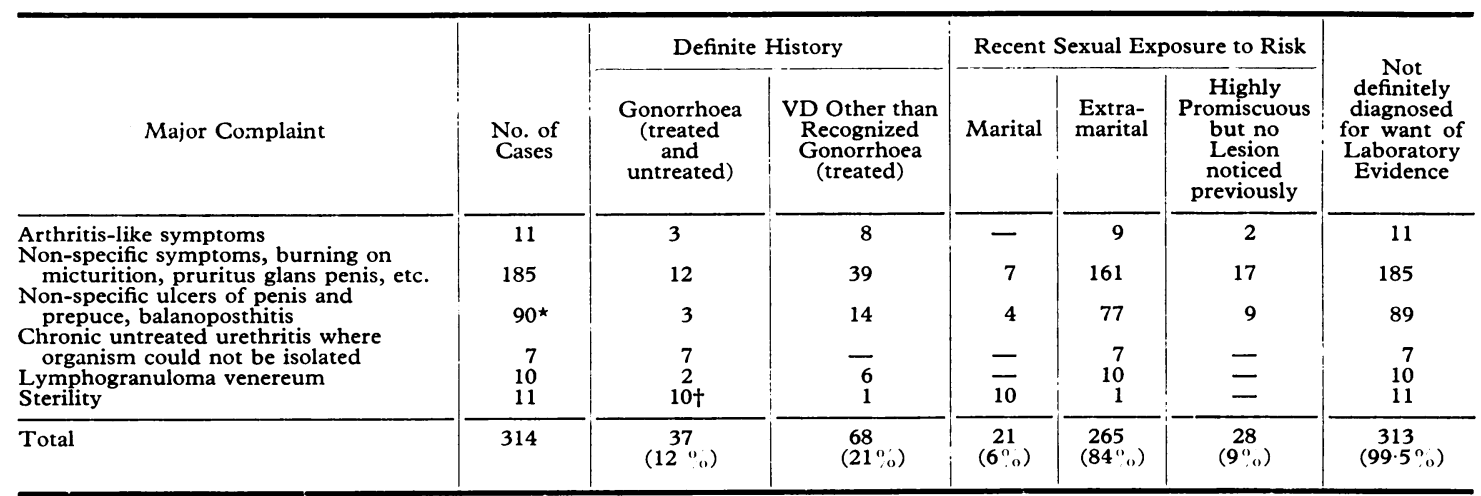

^In one case of sub-preputial ulcer $N$. gonorrhoeae was isolated.

tIn all ten cases, the wives had a history of white vaginal discharge but were not available for detailed examination. 
their microprecipitin test. This was reported to have been non-reactive in 22 laboratory personnel and forty teenage boys, giving 100 per cent. specificity. This may indicate that a higher "trend of specificity" is obtained by their method, but their test would need more extensive evaluation, particularly with regard to its Neisserian "species specificity".

With regard to the "absolute specificity" of our microprecipitin test, positive results that are not supported by clinical and epidemiological evidence may be considered to reflect cross-reactivity against related species of Neisseria. In this connexion, the non-reactivity of Reising and Kellogg's test in eleven "meningococcal carriers" are interesting, but the numbers are too small for definite conclusions to be drawn. Perhaps more significant was the result of their experimental "gel-diffusion" study, which showed no "precipitin bands" by the phenol extract antigen in rabbit hyperimmune-antisera against $N$. meningitidis, while it did show one against $N$. gonorrhoeae.

Since members of the Neisseria group are known to have some antigens in common, it would have been relevant to check the nonreactivity of a microprecipitin test for gonorrhoea in specimens of serum and cerebrospinal fluid from human cases of meningococcal meningitis, both active and convalescent. Such specimens were not available to us in this study. Human "carriers" of meningococci and Neisseria catarrhalis, may pose problems of crossreactivity and absolute specificity, but the formation of specific antibodies in the serum of carriers of micro-organisms in general, has not been conclusively proved.

The presence of human carriers of $N$. meningitidis in the population groups involved in this study has been previously demonstrated (Chacko and Nair, 1968). Among adults, two out of 26 patients in the VD department, five out of 36 laboratory personnel, and one out of 38 female health visitor trainees ( 8 per cent. overall) were found to be healthy nasopharyngeal carriers of meningococci (unpublished data). In children attending the paediatric out-patients department of the Madras General Hospital, 32 (15 per cent.) of 213 were found to be meningococcal carriers (Chacko and Nair, 1968). Serological investigation of these cases by our microprecipitin test for gonorrhoea was not carried out during that earlier study, but in the few cases recently investigated, some meningococcal carriers were found to be reactive. However, only 8 per cent. of the patients in the VD department were meningococcal carriers, while 31 per cent. were reactive to the microprecipitin test for gonorrhoea, suggest- ing trends to sero-reactivity to infections other than meningococcal in that particular group. Thus the cross-reactivity of this microprecipitin test for gonorrhoea has not yet been conclusively established or excluded by a systematic study of an adequate number of human meningococcal carriers.

In a few known human carriers of $N$. catarrhalis investigated in this study, the microprecipitin test for gonorrhoea was non-reactive, but the numbers were too small for definite conclusions to be drawn.

In another experimental study (Nair and Chacko, 1967) of the antigenic analysis of the Neisseria group of organisms it was observed that the microprecipitin test for gonorrhoea was reactive in the sera of rabbits immunized with formalized cultured gonococci and also with lipopolysaccharide antigens; the test was cross-reactive in other rabbits immunized by the same methods but with meningococci. Furthermore, as mentioned above, the microprecipitin test was reactive in the sera of human meningococcal carriers, in the few instances investigated. However, differences were observed between the sera of human carriers and rabbit hyperimmune sera against both gonococci and meningococci, in that while the rabbit sera were completely absorbed of precipitin reactivity, the human sera continued to show residual precipitin reactivity when absorbed with either gonococcal or meningococcal cells (Nair and Chacko, 1967). This suggested than an additional immunologically active lipopolysaccharide constituent may be present in virulent Neisseria cells when active in the production of human disease and of specific antibody; this evidence is absent in the sera of rabbits immunized with killed artificially cultured gonococci.

Moreover, this cross-reactivity between the gonococcus and the serum of human meningococcal carriers and anti-meningococcal serum of rabbit origin was observed when the gonococcus was stained by the immuno-fluorescence technique. In gel-diffusion experiments also, similar patterns of precipitation bands were observed in the two types of cross-reacting sera. This suggests a possible sharing of the lipopolysaccharide antigenic factor between the gonococcus and the meningococcus (data awaiting publication). Consequently, there is the possibility that this microprecipitin test for gonorrhoea, as devised at present, may not be able to differentiate human anti-gonococcal serum from anti-meningococcal serum. The test clearly requires further systematic investigation in all its aspects, and particularly the extent to which the meningococcal carrier state affects its absolute specificity. 
The fundamental question involved is whether the polysaccharide antigen used in this test, or the phenol extract antigen used by Reising and Kellogg, is "species specific" for the gonococcus.

It was interesting to observe that our microprecipitin test was not reactive in the few human sera from carriers of $N$. catarrhalis or in the rabbit hyperimmune sera against formalized cultured $N$. catarrhalis. In the gel-diffusion test also, no precipitin band was observed between the lipopolysaccharide antigen of the gonococcus and $N$. catarrhalis anti-sera in the human carriers and in the rabbit immunized with it.

\section{Summary}

A simple microprecipitin ring test devised for the sero-diagnosis of gonorrhoea, using a lipopolysaccharide antigen derived from $N$. gonorrhoeae has been evaluated. The sensitivity of this test in known cases of early acute gonococcal urethritis has been observed to be high; it can be used to screen blood specimens for gonococcal infection anonymously in the course of systematic blood investigations. It may be expected to be particularly useful in the detection of the asymptomatic female carriers who may maintain a reservoir of gonococcal infection. It may also confirm the clinical diagnosis of the late sequelae of gonorrhoea in both sexes. The specificity of the test in non-gonococcal diseases appears to be satisfactory, except for its apparent cross-reactivity with cases of meningococcal infection. "Carriers" of meningococci may be reactive to this test, and this aspect needs more extensive study, as does the question whether the polysaccharide antigenic constituent of $N$. gonorrhoeae is species specific or group specific.

The authors acknowledge gratefully the special laboratory facilities provided for this study at the Central VD Reference Laboratory at Madras by the Government of India, the Government of Madras, and the World Health Organization. They also thank the following for their co-operation and help: Prof. P. N. Rangiah, Director of the Madras Institute of Venereology, Dr. C. N. Soumini, Associate Professor of
Venereology, who provided the relevant clinical material and data, Prof. M. K. Krishna Menon, Director of the Institute of Obstetrics and Gynaecology, assisted by Dr. A. Nafessa Bee, who provided the relevant data and clinical material from the antenatal and gynaecological department, and the clinical and laboratory staff of the Madras Institute of Venereology for their help in carrying out this study.

\section{REFERENCES}

Chacko, C. W., and NaIR, G. M. (1966a). Ann. Indian Acad. med. Sci., 2, 35. (1966b). Indian F. Derm. Vener., 32, 41 (WHO/VDT/RES/GON/66.12).

- - (1968). Brit. F. vener. Dis., 44, 67.

NaIR, G. M., and CHACKo, C. W. (1966). Ann. Indian Acad. med. Sci., 2, 231.

- - (1967). Indian F. Derm. Vener., 33, 53.

Reising, G., and Kellogg, D. S., Jr. (1965). Proc. Soc. exp. Biol. (N.Y.), 120, 660.

Le séro-diagnostic de la blennorragie par un test de microprécipitine employant un antigène lipopolysaccharide obtenu du $N$. gonorrhoeae

\section{RÉsumé}

Un test simple spéciale comprenant un cercle de microprécipitine pour le séro-diagnostic de la blennorragie employant un antigène lipopolysaccharide dérivé du $N$. gonorrhoeae a été évalué. La sensibilité de ce test dans les cas connus d'urétrite blennorragique aiguë précoce a été observé comme étant élevée; il peut être employé pour passer au crible des spécimens anonymes de sang pour déceler l'infection blennorragique au cours des études systématiques de sang. On peut espérer qu'il sera particulièrement utile dans la découverte des porteuses asymptomatiques qui pourraient maintenir un réservoir d'infection blennorragique. Il pourrait aussi confirmer le diagnostic clinique des séquelles tardives de la blennorragie chez les deux sexes. La spécificité de ce test dans les maladies non-blennorragiques semble être satisfaisante excepté par sa réactivité croisée apparente dans les infections causées par les méningocoques. Les "porteurs" de méningocoques pourraient réagir à ce test, et cet aspect demande une étude plus étendue, ainsi que la question de savoir si le constituant antigénique polysaccharide du $N$. gonorrhoeae est spécifique de l'espèce ou du groupe. 